\begin{tabular}{|c|c|c|}
\hline & $\begin{array}{l}\text { European Association for the } \\
\text { Development of Renewable Energies, Environment } \\
\text { and Power Quality (EA4EPQ) }\end{array}$ & $\begin{array}{l}\text { International Conference on Renewable Energies and Power Quality } \\
\text { (ICREPQ'12) } \\
\text { Santiago de Compostela (Spain), 28th to 30th March, } 2012\end{array}$ \\
\hline
\end{tabular}

\title{
Energy conservation using high-efficiency electric motors
}

\author{
Engineer Sergio Roberto Jardim and Prof Gilmar Barreto, PhD
}

\author{
State University of Campinas - UNICAMP, \\ School of Electrical and Computer Engineering - FEEC, \\ Department of Machine Components and Smart Systems - DMCSI - \\ Av. Albert Einstein, 400 - Cidade Universitária Zeferino Vaz- \\ Barão Geraldo - Campinas - SP - CEP: 13083-852 - Brazil - \\ Phone number: +551196312065, +551135213817 \\ e-mail:sergiojardim@squadcorp.com.br, gbarreto@dmcsi.fee.unicamp.br
}

\begin{abstract}
The current policy to keep and rationally use energy in Brazil is focused on allocating energy resources efficiently and preserving the environment. Thus, understanding the legislation and the problems tied in with inadequate consumption of energy promotes creating basic parameters and formation of industrial policies to keep energy efficiently. Moreover, it offers using better the available resources at a lower cost.

Given the current policy of Conservation and Rational Use of Energy in Brazil, which aims at the efficient allocation of energy resources and preserving the environment, understanding the Legislation and the problems related to inadequate consumption of energy promotes the creation of basic parameters as well as industrial policies of conservation and energy efficiency that will promote a better use of available resources at lower costs. We can say that of all the motors used in industry, the electric induction motor is the most used, as it combines the advantages of using electric power, low manufacturing costs, ease of transport, cleaning, simplicity in control and mechanical robustness with its simple construction, versatility to adapt to various types of loads and better performance. The purpose of this study is to highlight this theme and its contributions.
\end{abstract}

\section{Key words}

Energy efficiency, Energy conservation, Electric motors.

\section{Introduction}

Managing and conserving energy is hugely important. In this respect, scholars, entrepreneurs, and various government sectors have been working to conserve energy efficiently in diverse sectors.

Bringing practicality to the academic environment, searching energy-saving solutions by debating how to solve problems and assessing the level Brazil developed since the creation of the Energy Efficiency Law (Law No.
$10,295,17$ October 2001) is pivotal to the development of the energy sector in Brazil.

Understanding the legislation and the problems related with inadequate consumption of energy promotes the creation of basic parameters as well as the formation of industrial policies to preserve energy efficiently. Moreover, it offers using better the available resources at a lower cost.

New opportunities for R\&D both in the energy and productive sectors have surfaced and brought us possibilities for technological advances. The purpose of this study is to highlight such theme and its contributions.

\section{Energy Efficiency}

According to information disclosed on the Banco de Informações de Geração da Agência Nacional de Energia Elétrica (Information Bank of the National Agency for Electricity Generation), the energy produced in Brazil from hydraulic power plants represents $66.27 \%$ of total electricity production. At these plants, the potential energy of water is transformed into kinetic energy which, in turn, is transformed into electrical energy by electromechanical conversion that occurs within the synchronous machines [1].

Studying how electricity consumption increases is an indicator of the socio-economic behaviour of a society.

Aspects such as industrial production growth, demographic development, and insertion of new conservation habits are strongly linked to the use of electricity as a basic resource.

Thus, we can define energy efficiency as an activity that seeks to improve the use of available energy sources, whether renewable or not.

We will be able to achieve satisfactory levels of energy efficiency when we meet the need for energy of all segments of society without requiring investment in new 
sources of energy, i.e. when we can use the resources already available in a better and smarter way.

\subsection{Growth forecast of industry share in relation to Brazilian GDP}

According to the information contained in the Plano Decenal de Energia - PDE (Ten Year Energy Plan) 20102019, published by the Empresa de Pesquisa EnergéticaEPE (Energy Research Company), for the indicated horizon, industrial evolution will have a relative participation in the Brazilian GDP, i.e. 26.6\% 2010-2014 and 27.3\% 2015-2019 (EPE 2010 - Ten Year Energy Plan 2010-2019) [2].

\subsection{Energy consumption in Brazil}

According to what was verified in the 2010 Balanço Energético Nacional - BEN (National Energy Balance), energy consumption in Brazil is represented by seven different sectors. The sectors are: industrial, responsible for nearly $37 \%$ of total consumption; residential, for roughly $11 \%$; commercial, for nearly $3 \%$; public, for nearly $2 \%$; agriculture, for roughly $5 \%$; energy sector, for nearly $12 \%$ and transport, for nearly $30 \%$ of all energy demand in the country.

Importantly, the two largest consumers are subdivided. The transport sector is divided into Motorway, Railway, Air and Waterway.

The industrial sector is subdivided into Cement, Pig iron and Steel, Iron alloys, Mining and Pelletising, Chemical, Non-ferrous and others from Metallurgy, Textile, Food and Beverage, Pulp \& Paper, Ceramics, and, finally, other industries. (EPE 2010-BEN 2010 - Base Year 2009). [3]

\subsection{Electricity generation and consumption in Brazil}

Generating electricity energy in Brazil reached 466.2 TWH in 2009, while net imports were $40.0 \mathrm{TWH}$. Together, they allow a domestic supply of 506.1 TWH of electricity, an amount of $0.2 \%$ superior to 2008, (EPE 2010-BEN 2010 - Base Year 2009).

Currently, Brazil has nearly 190 million inhabitants and, according to the Monthly Review of the Electricity Market in December 2010, the cumulative energy consumption from November 2009 to November 2010 totalled more than 417 TWH. The highlight was the increase in residential energy consumption in the Northeast. The report said growth in consumption is related to the increase in employment and income transfer programmes. According to the Cadastro Geral de Empregados $e$ Desempregados - CAGED (General Register of Employed and Unemployed), an entity linked to the Ministry of Labour and Employment, from January to October 2010, 383,000 formal jobs were created in the region, thus increasing the consumption of electricity in the country (EPE 2010 - Monthly Review of the Electricity Market) $[4]$.

\subsection{Electricity consumption in Brazilian industry}

The electricity consumption in Brazil totalled 417,434 GWH in 2010 according to the Energy Research Company (EPE), a company linked to the Ministry of Mines and Energy, a rise in $8.1 \%$ compared to the same period of 2009. The Brazilian industry represented $43.82 \%$ from total consumption in the country.

The amount of electricity consumed by the industry is divided according to the segmentation shown on the National Energy Balance (BEN, 2010), presented in figure 1. [5]

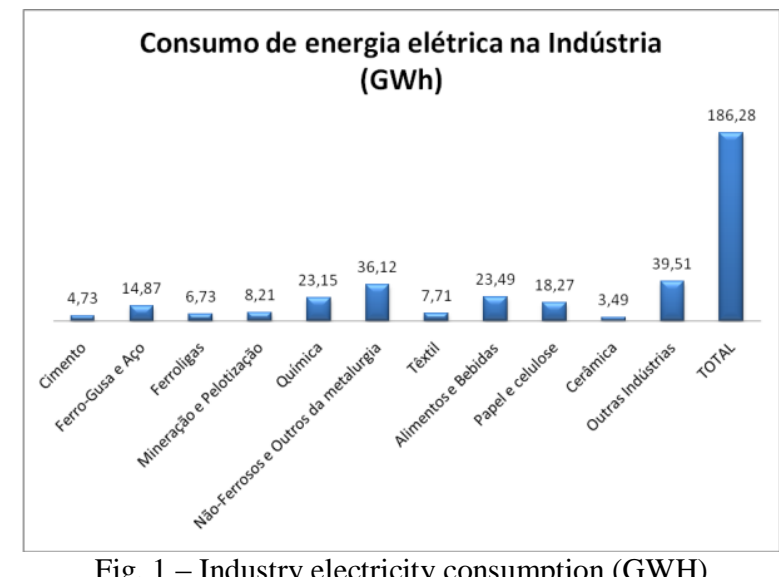

Fig. 1 - Industry electricity consumption (GWH) Source: National Energy Balance (BEN).

Key: Figure 1

Industry electricity consumption $(\mathrm{GWH})$

Cement,

Pig iron and Steel

Iron alloys

Mining and Pelletising

Chemistry

Non-ferrous and others from metallurgy

Textile

Food \& Beverage

Pulp \& Paper

Ceramics

Other industries

Total

\subsection{Distribution of Electric Energy Consumption in Brazilian Industry}

According to the latest Research Report on Ownership of Equipment and Consumption Habits, prepared by PROCEL/ELETROBRAS, published in Brazil in 2008, we can verify that in the Brazilian industry, with the main drive systems, that is, those using electric motors, the compressed and vacuum air systems are more present, with a share of $72 \%$ of consumption, followed by pumping systems with $59 \%$ of the movement, handling and treatment with $47 \%$ and ventilation with $46 \%$.

The report also states that there is a policy to manage energy facilities. 
The absence of such actions presents itself as an expressive potential to improve energy efficiency in the sector.

In general, the costs of electricity represent on average of nearly $10 \%$ of the total costs of companies.

In contrast, sectors such as wood products $(45 \%)$, basic metallurgy $(12.4 \%)$, non-metallic mineral products $(11.4 \%)$, leather $(14.7 \%)$, recycling $(14.4 \%)$ participate with significant percentages of their production costs in the use electricity.

Such participation slightly defines the propensity for these industries to invest in energy efficiency measures.

Figure 2 presents how consumption of motive power from electric motors in the Brazilian industry is distributed (Eletrobras/PROCEL - Research on Ownership of Equipment and Use Habits) [5].

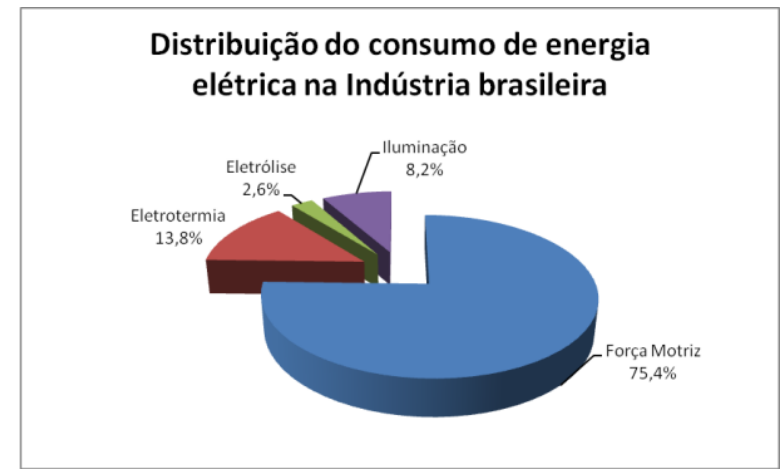

Fig. 2 - Industry electricity consumption Source: Research Report on Ownership of Equipment and Consumption Habits

Key: Figure 2

Distribution of energy consumption in Brazilian industry

Electric heating

Electrolysis

Lighting

Driving force

\subsection{Contribution of energy consumption by electric induction motors in Brazilian industry}

The information taken from the Research Report on Ownership of Electrical Equipment and Consumption Habits gave us subsidies to assess that $75.4 \%$ of electricity consumption in the industry come from electric motors.

We can thus transform the graph provided by the National Energy Balance, which shows the energy consumption in the industry, to obtain the electricity consumption used in the industry only for the use of induction motors (figure 3).

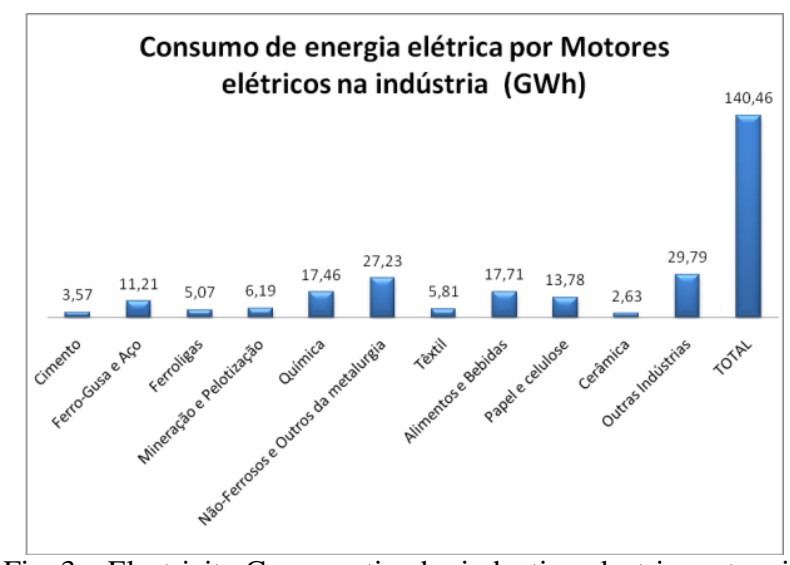

Fig. 3 - Electricity Consumption by induction electric motors in Brazilian industry

Key: figure 3

Electricity consumption by electric motors in industry (GWH)

Cement,

Pig iron and Steel

Iron alloys

Mining and Pelletising

Chemistry

Non-ferrous and other from metallurgy

Textile

Food \& Beverage

Pulp \& Paper

Ceramics

Other industries

TOTAL

Assessing the performance indexes mentioned in the Interministerial Directive No. 553 (8 December 2005), based on Law 10,295, we can establish for the purpose of interpretation that, nowadays three-phase electric motors to be used in Brazil must have indexes to improve performance in at least $2 \%$ in average. This would represent a drop in total energy consumption in the industry of roughly $2.8 \mathrm{GWH}$.

\section{Energy Efficiency}

\subsection{Energy crisis in Brazil}

Most of the energy produced in Brazil comes from hydroelectric plants. The volume of water in the reservoirs of such plants must always be adequate to the perfect operation of the system.

Periods of rain with less intensity, lack of investments in the sector, and in particular lack of planning by government and regulating agencies, contributed to several 'blackouts' during the last decades.

Throughout its history, Brazil has faced several situations involving lack of energy, however, 2001 was determinant with the rationing, the increase in the price of electricity and the encouragement to reduce energy consumption in all Brazilian sectors.

In that year, through Provisional Measure No. 2147 (15 May 2001), the government of President Fernando Henrique Cardoso created and installed the Electricity 
Crisis Management Chamber which established guidelines for programmes to fight the energy crisis.

After that, the government settled special pricing, usage limits and electricity supply as well as measures to reduce consumption.

The most significant result for the Brazilian population was when people were obliged to consume less residential electricity (20\%), under penalty of fines and energy cuts. Dismissal of part of the employees from the industry and the search for electronic lamps, for generators and for higher-efficiency motors could also be verified at the time. Isolated actions from state and local governments to achieve the goals set by the federal government, e.g. public power cuts in parts of São Paulo and reduction in public services, were adopted.

\subsection{Brazilian legislation of energy efficiency}

In 1984, realising the deficiency of the energy sector, INMETRO (National Institute of Metrology, Quality and Technology) - linked to the Ministry of Development, Industry and Foreign Trade - started discussing the matter of energy efficiency with Brazilian society, seeking to rationalise the use of various types of energy. The aim was to inform consumers on how efficient each product is and encourage them to think about what they were buying.

At the beginning, the project was linked to the automotive industry, and, with its growth and acceptance, it received the status of Brazilian Labelling Programme, acting mainly in energy consuming products.

In the face of the Brazilian energy crisis in 2001, the government decided to recover and publish a bill of the Senate which established a national policy on energy efficiency for machines and appliances that use electricity sold in the country.

This law was enacted by the President on 17 October 2001, Law No. 10,295, stating that the Executive Branch should establish maximum or minimum levels of consumption for energy used by machines and appliances, sold in the country.

It was also established that, within one year, from the regulation for each product, a programme of goals would be drawn up for a progressive evolution of the indexes.

The next step after publication of the law was to create and publish Decree 4,059, which regulated the Law and established the points to be addressed for the specific regulation of each product (technical reference standards, mechanism to assess compliance, levels to be achieved, inspection, etc). It also established that INMETRO would be responsible for programmes to monitor and assess the conformity in Brazil.

The Decree was responsible for the creation of the Comite Gestor de Indicadores e Níveis de Eficiência EnergéticaCGIEE (Management Committee for Indicators and Levels of Energy Efficiency), to develop specific regulations for each type of machine and machineconsuming energy.

From this decree, INMETRO voluntarily established labelling programmes, which had the responsibility to establish the conformity assessment programmes, compulsory in the field of energy performance. It was, therefore, essential in implementing the Energy Efficiency Law [8] - [13].

\subsection{Timeline of Brazilian legislation of efficiency in electric motors}

Law No. 10,295 - 17October2001: The Executive Branch determined that the Union should establish maximum levels of specific energy consumption, or minimum energy efficiency of machines and appliances that use energy produced or marketed in Brazil, based on relevant technical indicators.

Non-compliance with these rules would bring about penalties to the offenders foreseen in the Law (a fine of up to $100 \%$ of the sales price practised per equipment found).

Decree No. 4,059 - 19December 2001: Instituted the CGIEE, chaired and coordinated by the Ministry of Mines and Energy.

Decree No4,508 - 11December 2002: Defined the minimum levels of energy efficiency of three-phase electric motors of squirrel-cage rotor induction (standard, high-performance) domestically manufactured (or imported) for sale or use in Brazil.

Ministerial Directive No.553 - 8December2005: Established minimum levels of nominal income to be met by the three-phase induction motors, without distinction of levels of nominal income between the standard and high-performance lines.

The deadline for manufacturing or importing, as well as marketing, was changed to four years after this Directive became effective.

INMETRO Directive No.243 - 4September 2009: Approved the Requirements for Conformity Assessment (RAC) for three-phase electric motors of squirrel-cage rotor induction and mandatory labelling for these motors sold apart or coupled in driving end-use machines [8] [13].

By way of understanding the current situation, the process for certification of the leading manufacturers of induction motors in Brazil occurred in an orderly and relatively fast manner, considering that they already lines of motors that met the new legislation perfectly .

From that point, new processes for energy conservation and energy efficiency gained strength in Brazil as well as new equipment now have legislation and specific classification as to the consumption of electricity for its operation.

\section{High-Efficiency Electric Motors}

\subsection{Introduction}

High-efficiency motors are those designed to provide the same useful power in its output shaft by using less network energy when compared with ordinary motors.

At first, the decisive criteria to select high-efficiency motors for many consumers was the relationship between the values of energy consumption during the life of the motor and its initial purchase price. 
According to motor manufacturers, energy consumption during the life of the motors could reach 100 times its initial purchase price. Thus, the performance of the motor was used as decisive criteria for the choice between buying new motors and repairing old motors.

For these and other reasons, some companies have adopted motor management policies, minimising their costs through the appropriate use of electricity. As important as choosing a high-efficiency motor is to design it correctly.

\subsection{Basic characteristics or technical differences to compare high-efficiency induction motors}

To reduce losses and increase performance, highperformance motors present:

- Sheet metal with low losses (silicon steel) that reduce the magnetising current and iron losses;

- Special dual-layer windings that reduce additional losses;

- Rotor heat treated to reduce additional losses (rotor losses);

- $\quad$ Ring short circuit and rotor bars super-sized to reduce Joule losses;

- Design of slot stator for a higher fill factor, thus reducing winding Joule losses;

- Enhancement of the materials making up the motor insulation system (wires, insulating films, impregnation systems, varnish, cables and other components).

\subsection{Considerations to select induction Electric motors}

To correctly select and design induction electric motors one needs to know the equipment and how it affects the process as a whole, its main operating characteristics, the type of coupling, the power consumed, conjugates, service system, inertia, etc.

To know the characteristics of the power supply (voltage, frequency) and the environment where the equipment will be used is also essential.

Basic criteria to design motors involve:

- Effective Power Criterion;

- of Motor Maximum Conjugate Criterion;

- Discretion of Motor Conjugates and Resistant;

- Acceleration Time Criterion;

- Available Power Criterion.

\section{Conclusions}

Herein, we discussed the overall picture of energy consumption in Brazil and the drop in the energy consumption provided by high-performance motors.

The history of the energy crisis in Brazil and the evolution of Brazilian legislation on energy efficiency in induction motors were demonstrated.

Quantitative analysis aimed at replacing traditional motors with motors meeting current regulations has been developed and will be presented in future studies.
Preliminary analysis indicates a growth in more than $600 \%$, if we compare the current volume of motors sold in 2011 with sales volume in 2009, when it was not compulsory to use these motors yet.

We also consider that $70 \%$ of these new motors are intended for new installations and $30 \%$ to replace the market.

Thus, there is a need for a policy for energy management in industrial plants in Brazil, in particular seeking to understand the relationship between the competitiveness of the domestic industrial production and the reduced share of electricity input when making up total production costs.

In contrast, there are some points we should think over:

- What is the impact of Law 10,295 on the Brazilian energy matrix? Will there be effective gains?

- What has been done to accomplish this Law effectively? Is there a plan to verify the legislation effectively?

- What has been done to ensure that the imported equipment with induction motors from other countries meets the Brazilian legislation?

- What are the investments needed to achieve a bit more than $2 \%$ of income? How long will it take for the energy savings to pay for the necessary investment?

Therefore, for satisfactory answers to such questions, working groups, e.g. researchers, entrepreneurs, government agencies and users must be created, encouraged and supported.

\section{References}

[1] BIG/ANEEL - Banco de Informações de Geração da Agência Nacional de Energia Elétrica - Capacidade de Geração do Brasil -Source: http://www.aneel.gov.br/aplicacoes/capacidadebrasil/capacidad ebrasil.asp

[2] EPE - Empresa de Pesquisa Energética (2010). Plano Decenal de Energia 2010-2019 - Nota Técnica DEA 13/10 Caracterização do Cenário Macroeconômico, página 31 . Source:

http://www.epe.gov.br/mercado/Documents/S\%C3\%A9rie\%20 Estudos\%20de\%20Energia/20100809 3.pdf

[3] EPE - Empresa de Pesquisa Energética (2010). Balanço Energético Nacional 2010 - BEN - Ano Base 2009, páginas 11, 23 e $28 \quad-\quad$ Source: https://ben.epe.gov.br/downloads/Relatorio_Final_BEN_2010.p $\underline{\mathrm{df}}$

[4] EPE - Empresa de Pesquisa Energética (2010). Resenha mensal o Mercado de Energia Elétrica - Ano IV - No 39 Dezembro de 2010 - Publicação da Diretoria de Estudos Econômico-Energéticos e Ambientais - Source: http://www.epe.gov.br/ResenhaMensal/20101222_1.pdf

[5] ELETROBRAS/PROCEL - Centrais Elétricas Brasileiras S.A. / Programa Nacional de Conservação de Energia Elétrica (2010).

Pesquisa de Posse de Equipamentos e Hábitos de Uso - Ano Base 2005 - Diretoria de Tecnologia - Consórcio ECOLUZ / PUC - Rio Departamento de Planejamento e Estudos de Eficiência Energética - Published on March 2008 - Source: http://www.eletrobras.com/pci/main.asp 
[6] INMETRO - Instituto Nacional de Metrologia, Normalização e Qualidade Industrial - Apostila de eficiência energética Source: http://www.inmetro.gov.br/qualidade/eficiencia.asp

[7] LOBOSCO, O. S., DIAS, J. L. P. DA (1988) - Seleção e Aplicação de Motores Elétricos. - Ed. McGraw-Hill.

[8] MINISTÉRIO DE MINAS E ENERGIA - Consultoria Jurídica - Portaria Interministerial $N^{\circ} 553$ de 08 de Dezembro de 2005 Source: http://www.mme.gov.br/mme/galerias/arquivos/legislacao/portari a_interminestral/Portaria_MME-MCT-MDIC_no_553-2005.pdf

[9] MINISTÉRIO DO DESENVOLVIMENTO, INDÚSTRIA E COMÉRCIO EXTERIOR - Instituto Nacional de Metrologia, Normalização e Qualidade Industrial - INMETRO - Portaria Inmetro $\mathrm{n}^{\circ}$ 243, de 04 de setembro de 2009 - Source: http://www.inmetro.gov.br/legislacao/rtac/pdf/RTAC001485.pdf [10] PRESIDÊNCIA DA REPÚBLICA - Casa Civil - Subchefia para assuntos Jurídicos - Lei No 10.295, de 17 de Outubro de $2001 \quad-\quad$ Source: http://www.planalto.gov.br/ccivil_03/Leis/LEIS_2001/L10295.ht $\underline{\mathrm{m}}$

[11] PRESIDÊNCIA DA REPÚBLICA - Casa Civil - Subchefia para assuntos Jurídicos - Decreto $\mathrm{N}^{\circ} 4.508$, de 11 de Dezembro de $2002 \quad-\quad$ Source: http://www.planalto.gov.br/ccivil_03/decreto/2002/D4508.htm

[12] PROCEL - Programa Nacional de Conservação de Energia Elétrica - Informação ao consumidor - Source: http://www.inmetro.gov.br/consumidor/etiquetas.asp

[13] SENADO FEDERAL - Subsecretaria de Informações Decreto $N^{\circ}$ 4.059, de 19 de Dezembro de 2001 - Source: http://www6.senado.gov.br/legislacao/ListaPublicacoes.action?id $=234101$

[14] WEG Equipamentos Elétricos S/A - Manual de Motores elétricos $\quad(050.09 / 112009) \quad-\quad$ Source: http://www.weg.net/files/products/WEG-motores-eletricos-baixatensao-mercado-brasil-050-catalogo-portugues-br.pdf 